\title{
National Health Insurance Deficit in Indonesia: Identification of Causes and Solutions for Resolution
}

\author{
Wahyu P. Nugraheni ${ }^{1}$, Asri Hikmatuz Zahroh ${ }^{2}$, Risky Kusuma Hartono ${ }^{3}$, \\ Ryan Rachmad Nugraha ${ }^{4} \&$ Chang Bae Chun ${ }^{5}$ \\ ${ }^{1}$ National Institute of Health Research and Development, Ministry of Health Republic of Indonesia, Jakarta, \\ Indonesia \\ ${ }^{2}$ Jakarta Health Polytechnic III, Ministry of Health Republic of Indonesia, Jakarta, Indonesia \\ ${ }^{3}$ Sekolah Tinggi Ilmu Kesehatan Indonesia Maju, Jakarta, Indonesia \\ ${ }^{4}$ Thinkwell, Jakarta, Indonesia \\ ${ }^{5}$ Department of Health Management, Woosong University, Daejeon, South Korea \\ Correspondence: Wahyu P. Nugraheni, National Institute of Health Research and Development, Ministry of \\ Health Republic of Indonesia, Jakarta, Indonesia. Tel: 62-812-802-0500. E-mail: nugraheni_wp@yahoo.com
}

Received: September 18, 2020 Accepted: October 19, 2020 Online Published: October 30, 2020

doi:10.5539/gjhs.v12n13p58 URL: https://doi.org/10.5539/gjhs.v12n13p58

\begin{abstract}
Introduction: Since it was implemented in 2014, National Health Insurance Program (JKN) in Indonesia experienced a financial deficit. JKN recorded a deficit of 9.7 trillion, 9.75 trillion and 10.98 trillion rupiah from 2016-2018, respectively. The deficit is estimated to still continue in the upcoming years. Systemic solutions are needed to bring JKN improvement in the future.
\end{abstract}

Methods: Data was collected from June to December 2019 by in-depth interviews with selected informants and literature review, which later was analyzed by content and with data triangulation.

Result: The results of in-depth interviews and a review of some of the literature shows that there are four main factors that causes JKN deficit, which are capitation payment system to provider, the alleged fraud, lag of backed-referral system, and catastrophic disease.

Conclusion: This study provides a solution to the handling of JKN deficits in the short and long term in accordance with problems in terms of funding and JKN expenditure. The solution can be an alternative policy that can be implemented by the Government of Indonesia to deal with the JKN deficit.

Keywords: deficit, Indonesia, national health insurance, qualitative

\section{Introduction}

Since it was implemented in 2014, National Health Insurance (NHI) Program of Indonesia (Jaminan Kesehatan Indonesia/JKN) have been experiencing deficit, characterized by the negative balance of expenditure compared to its revenue. JKN subsequently recorded a deficit of 9.7 trillion, 9.75 trillion and 10.98 trillion rupiah from 2016-2018, respectively, and is anticipated to persist in upcoming years. While the number of JKN participants is increased every year along with the revision of contribution, contributions amount is not sufficient to cover all health claims. As happened in 2016, the amount of contributions received by the Social Security Agency for Health (BPJS-Health) was IDR 67.4 trillion but the claim burden was IDR 73.5 trillion (Hasan, 2017). Deficit condition was strongly suspected due to over utilization of health services by insurance participants and the Supply-Induced Demand (SID) phenomenon in healthcare provider (Hidayat, 2016).

Suggestions for solving the deficit solutions have been offered and put forward by various parties. However, the settlement of deficit has been carried out by giving an injection of government subsidies for JKN program. Such settlement is not sustainable and cannot change JKN financial condition in the future. Systemic solutions are needed to bring about JKN improvement in the future. Therefore, it is necessary to conduct research to figure out the root cause of deficit in JKN program. 


\section{Methodology}

\subsection{Study Design}

This study used qualitative research method with case study approach. This study was retrospective method in order to look at the past event especially the policy of BPJS-Health.

\subsection{Time and Participants}

Data was collected from June to December 2019 by literature review and in-depth interviews to selected informants. The informants of this study are officials of Ministry of Health, Ministry of Finance, BPJS-Health, National Social Security Council (DJSN), Public Health Center (Puskesmas), Health Professional Organizations, and three academic experts.

\subsection{Procedure of Study}

This study was started with literature review on the handling of deficit of NHI from various countries. Data collection was proceeded after literature review by conducting in-depth interview. The interview was conducted by using the structured guideline of questions. Secondary data collection was also investigated by collecting the documents related to BPJS-Health. The data collection was started after the study protocol had been approved by the ethical committee and seeking for the confirmation from the informant for indept-interview.

\subsection{Aspect of the Study}

There are two aspects to identify the root problems of deficit in JKN program, which is income (or revenue) aspect and expenditure aspect. Income aspects are seen in terms of the formulary of contribution and collectability. Whereas the expenditure aspect entails the benefit package, payment and tariff system, the alleged fraud in health facilities as well as the utilization of health services.

\subsection{Data Analysis}

Content analysis method used to analyze the data. The analysis stage was begun by examining all the available data from interviews, observations, official documents, and literatures. The next step was to triangulate data sources and to map JKN solutions in the short term and long term based on the identified issues.

\subsection{Ethical Consideration}

The protocol for the study was reviewed and approved by the National Institute of Health Research and Development, Ministry of Health Republic of Indonesia with the reference number: LB.02.01/2/KE.212/2019.

\section{Results and Discussion}

\subsection{Income Aspect}

3.1.1 The Determination of the Amount of JKN Participant Contributions is not in Accordance With Actuarial Calculations

Resolving JKN deficit requires comprehensive interventions, mainly in terms of revenue and expenditure. Since the JKN Program began its implementation in 2014, BPJS-Health revenue from participant contributions has increased every year in line with the increased number of JKN membership coverage. In 2014 overall contribution income was IDR 40.7 trillion, which increased to become Indonesian Rupiah (IDR) 52.7 Trillion in 2015, IDR 67.4 in 2016, IDR 74.2 Trillion in 2017 and eventually amounted to 81.8 Trillion in 2018. However, the burden of health insurance in the form of health services was also increasing; in 2014, the total cost of health services was IDR 42.65 trillion, in and became IDR 57.08 Trillion by 2015, to become IDR 67.28 Trillion in 2016, IDR 84.44 trillion in 2017 and eventually became IDR 94.29 Trillion in 2018. From these data it is seen that the increase in contribution rates was not able to offset the high increase health insurance burden.

The JKN program has been implemented by adopting a social health insurance system that involves community participation in its funding by requiring contribution payment. The amount of contribution was set by the proposal of National Social Security Council (DJSN), however, the published amount of contribution is lower than the ideal amount of contribution calculated by the DJSN. The DJSN proposal for JKN subsidized user's (Penerima Bantuan Iuran/PBI) contribution fee is IDR 36,000/month/person but the published amount of contribution was IDR 23,000/month/person, as stipulated in Presidential Decree No.19/2016. Such amount, being lower than estimation, was set considering the ability-to-pay rather than level risk of either individual or groups. The following are the pros and cons of the informant's statement about the calculation of contribution.

The calculation of contributions is in accordance with the principles of social insurance which refers to the Health Insurance Association. We have limited regional demographic data, we have not applied this (risk calculation) 
method, due to limited tools as well. It should refer to the morbidity table and it is not exist yet. The calculation is still a national aggregate. This is the limitations of the calculation (BPJS-Health).

...Not yet up to $100 \%$ because the basic principle of insurance is adequacy, meaning to fund all of the benefits of participants. That is the basic principle of inviolability... (Academic Expert 2).

Some countries have a variety of ways to collect NHI contributions to make sure sufficiency of fund to pay for provider's claim. South Korea in the National Health Insurance Service (NHIS) program sets contributions for workers based on the percentage of income/ wages paid together by workers and employers by $6.67 \%$, while for self-employed workers the contribution formula is based on income and property (Kwon, 2009). In Taiwan, NHI sets contributions based on a percentage of income individuals, a maximum of NT \$ 131,700 per month and paid together by workers with employers, for non-contributory workers are determined based on the ability to pay for high-income entrepreneurs paying $100 \%$ of their own contributions. The government pays $100 \%$ of contributions for military personnel and low unemployment, and pays $40 \%$ of the contribution for other unemployed (Lee et al., 2010). Increasing contributions and increasing the presentation of contribution from wages is also done by other countries in addressing the deficit of the health insurance program. Within the NHI program in Taiwan, the contribution increases and upper limit sets to 8.3 times the lowest income to overcome the deficit (Y. Ku, 2006).

3.1.2 The Upper Limit of Income Used in Calculating the Contribution of Workers Who Receive Wages (PPU) is Still Relatively Low

The other factor attributing to low revenue for JKN program is determination of wage limits which does not meet the principle of mutual cooperation. Wage limits that are too low will have an impact on the inequality of contributions to wage-recipient workers segment (Pekerja Penerima Upah/PPU). As illustrated in the table below, workers who have IDR 3.500.000 monthly income spend 5\% from their income for JKN contribution, but workers who have IDR 150.000 .000 monthly income spend only $0,4 \%$ from their income for JKN contribution. This is attributed to the policy design which allows the maximum contribution of $5 \%$ from maximum allowable income of IDR $12,000,000$. The wide income inequality of Indonesians makes it difficult to determine the wage limit. Another intervention that can be applied is to determine the amount of contributions based on income category (low-, middle-, and high income) so that payment contribution can be less skewed for covering JKN deficit.

Table 1. Percentage of contribution from monthly income of PPU Participants

\begin{tabular}{lcc}
\hline Monthly Income & Contribution Amount & Percentage of contribution from monthly income \\
\hline IDR 3.500 .000 & IDR 175.000 & $5,0 \%$ \\
IDR 4.000 .000 & IDR 200.000 & $5,0 \%$ \\
IDR 8.000 .000 & IDR 400.000 & $5,0 \%$ \\
IDR 9.000 .000 & IDR 450.000 & $5,0 \%$ \\
IDR 10.000 .000 & IDR 500.000 & $5,0 \%$ \\
IDR 12.000 .000 & IDR 600.000 & $5,0 \%$ \\
IDR 24.000 .000 & IDR 600.000 & $2,5 \%$ \\
IDR 48.000 .000 & IDR 600.000 & $1,25 \%$ \\
IDR 150.000 .000 & IDR 600.000 & $0,4 \%$ \\
\hline
\end{tabular}

In China, there is no wage limit on the proportion of NHI contributions paid by workers (He \& Wu, 2017). Other countries have also set high income limits, such as in Greece of 5,543.55 EUR or 7.3 times the average monthly income of the population (Deloitte, 2013). Whereas various other countries impose high limits on fees, Germany sets a limit on contributions of EUR 60,000 or $4 \%$ of the highest income (Deloitte, 2016). Korea sets a maximum contribution limit of 1,745,150 won (Chae, 2019).

\subsubsection{Low Collectability of Contributions from Non-Wage Worker Participants}

In terms of collectability, issues arise due to the lack of compliance in paying contributions. This condition causes inoptimality of contributions collectability, especially for Non-Wage Recipient Workers segment (Pekerja Bukan Penerima Upah/PBPU). According to a BPJS-Health informant, from total of 32 million PBPU, only $56 \%$ of participants paid contributions regularly every month. This statement is also supported by academic experts. 
... PBPU compliance is $56 \%$ and claim ratio is $300 \%$. It is followed by the low collectability. So, it's quite influential ... on average it has an impact. For PPU participants the collectability is almost $100 \%$... (BPJS-Health).

In private PPUs, there are companies that do not correctly report the number of employees and the amount of wages received. There are around 52\% PBPU participants and BP (not a worker/Bukan Pekerja/BP) around 5 million. Most of them did not pay their contribution orderly. It is also the causes of deficit .... (Academic Expert1).

Another problem from PBPU participants is the low coverage of membership, based on BPJS-Health membership data, PBPU participant coverage is only $42 \%$ of 73.9 million informal workers. Figure 2 is the coverage of PBPU participants in 2014-2018.

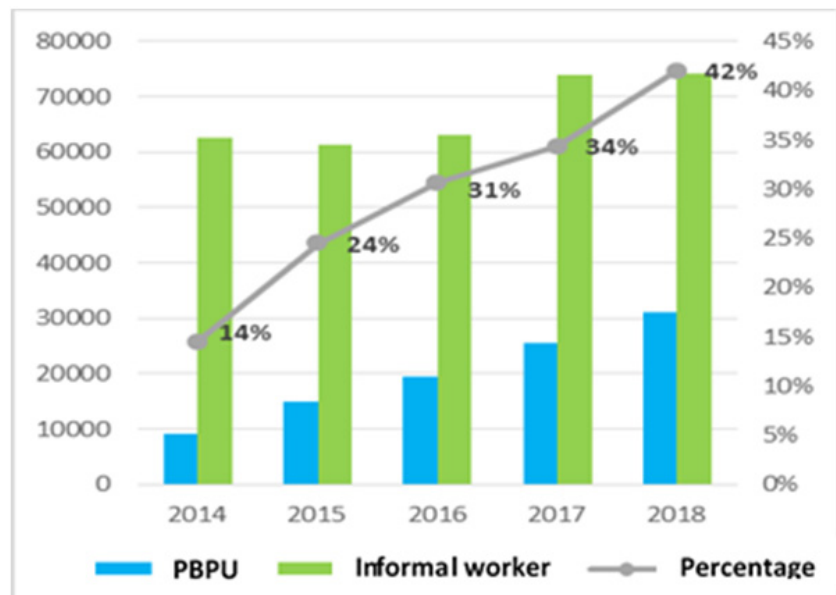

Figure 2. Coverage of PBPU Participants 2014-2018

Source: BPJS-Health and Indonesia Bureau of Statistics (BPS), 2014-2018

The collectivity of contribution is closely related to compliance of participants in paying contributions, mainly from PBPU segments, who are mostly informal sector workers. In this group, the compliance of paying dues is very dependent on the participants' awareness. PBPU participant contribution collectivity only reached $53.7 \%$, total PBPU participant arrears reached IDR 2.1 trillion in 2016, IDR 1.81 trillion in 2017 and IDR 2.12 trillion in 2018. The average PBPU participant arrears each year is equivalent to $2.5 \%$ of JKN participant contribution fee (BPJS-Health, 2019).

The cause of the low collectivity of PBPU participant contributions is related to the ability to pay contributions. According to Amalia et al., $87 \%$ of the informal sector has an income below the Indonesian standard wages, meaning that its majority falls on lower-middle class (Noeraini, 2015). Moreover, Mulyadita et al. suggests that PBPU participant's ability to pay contributions was only IDR32,000. The ability to pay is equivalent to $76 \%$ of the class 3 contribution, which is IDR 42,000 (Mulyadita, 2019).

There are three steps approach that can be taken to increase health insurance funding from informal sector workers, namely (i) expanding contribution subsidies not only to poor participants but also informal sector workers (ii) increasing the contribution of formal workers to subsidize informal workers (iii) a combination of payment of contributions by informal workers with government subsidies (partial subsidies) (Tangcharoensathien et al., 2011). Various countries have provided partial subsidies for informal workers to accelerate the achievement of Universal Health Coverage. The following countries provide subsidized health insurance contributions to informal workers. Vietnam provides a subsidy of $70 \%$, Mali provides a subsidy of $50 \%$, China provides a subsidy of $90 \%$, South Korea provides a subsidy of 40\% (Kwon, 2009; Liang et al., 2013; Tangcharoensathien et al., 2011).

According to Bonfert et al. partial subsidies can be an option for the State to implement a health insurance funding scheme for informal workers because it does not overburden State expenditures (Bonfert et al., 2015). The government has so far not taken steps to address problems in the informal sector group participants, or in this case PBPU participants. This delays the progress of resolution the problem of membership coverage and arrears of contributions by PBPU; and to address such, making simulations based on assumptions can be an option. The simulation is made with variations in the number of subsidies of $90 \%, 70 \%, 50 \%$ and $24 \%$ based on the application 
in other countries and the ability to pay class III PBPU participant contributions. From this simulation the government can determine the amount of the subsidy in accordance with the government's fiscal capacity.

Table 2. Simulation of Employee Sector Worker Subsidies that are not yet registered as BPJS-Health Participants

\begin{tabular}{lllcc}
\hline $\begin{array}{l}\text { Unregistered Informal } \\
\text { sector }\end{array}$ & $\begin{array}{l}\text { Class III contribution amount } \\
\text { (IDR) }\end{array}$ & Subsidy (\%) & Subsidy/person (IDR) & Subsidy/annual (IDR) \\
\hline 42.862 .000 & 42,000 & $90 \%$ & 37,800 & $6,4 \mathrm{~T}$ \\
42.862 .000 & 42,000 & $70 \%$ & 29,400 & $5,04 \mathrm{~T}$ \\
42.862 .000 & 42,000 & $50 \%$ & 21,000 & $3,6 \mathrm{~T}$ \\
42.862 .000 & 42,000 & $24 \%$ & 10,000 & $1,7 \mathrm{~T}$ \\
\hline
\end{tabular}

\subsubsection{JKN Income Obtained from Other Sources (for example from cigarette tax) is Still Low and not Optimal}

In Presidential Regulation 82 of 2018 concerning Health Insurance articles 99 and 100 states that the local government supports the implementation of the JKN program through a cigarette tax contribution of $75 \%$ of the $50 \%$ realization of cigarette tax revenue. However, the cigarette tax contribution from the local government has not been optimal because the cigarette tax revenue is used to pay contributions from Local Government Budget (Anggaran Pendapatan Belanja Daerah/APBD) PBI participants. These are the statement from the informants. The use of cigarette taxes to fund the health insurance of informal sector participants has been successfully implemented in other countries. South Korea uses a cigarette tax to fund a 3.5\% informal workers insurance program and the Philippines raises a cigarette tax to fund the health insurance of informal workers (Jeong, 2011). Indonesia has the same potential to provide partial subsidies to informal sector workers. Based on the results from Hasan, the potential cigarette tax levies from local governments is estimated at IDR 3.37 Trillion (Hasan, 2017). Another potential fund that can be considered is the diversion of fuel and gas subsidies. In addition, other potential funding sources come from the taxation on carbonated drinks and sweet drinks, such as those already implemented in Costa Rica, Jamaica and the UAE 18 countries.

Another potential fund that can be considered is the diversion of fuel and gas subsidies. In addition, other potential sources of funding come from the taxation of carbonated drinks and sweet drinks, as implemented in Mexico, Ecuador, Brunei Darussalam, Vanuatu, England, Portugal, India, South Africa, Saudi Arabia, the Philippines, Thailand and Sri Lanka (Oxford Policy Management, 2016).

\subsection{Expenditure Aspect}

The results of in-depth interviews and a review of some of the literature shows that there are four main factors that causes JKN deficit, which are capitation payment system to provider, the alleged fraud, lag of backed-referral system, and catastrophic disease.

\subsubsection{Determination of the Amount of Capitation Value Does not Consider to the Health Risks of Participants.}

The results of this study indicate that the distribution of JKN participants in each primary healthcare (FKTP) is uneven and does not pay attention to distribution based on participant characteristics such as age. Existing implementation of capitation payment sparks concern from professional organizations, thus it needs to be evaluated.

"If the capitation rate is not raised, we will declare that we will leave BPJS-Health, I am not afraid, PDGI (re: Indonesian National Dentist Association) is an independent institution not under BPJS-Health."

\section{(Indonesian National Dentist Association).}

"(The capitation amount is) Not yet appropriate because the calculations are not in accordance with the economic value in certain areas. For the private sector and the government, the values have been differentiated, but we still have to periodically evaluate it."

\section{(BPJS-Health)}

The calculation of capitation needs to pay attention to three components namely annual expenditure per patient in the previous year, age and gender adjustments based on changes in patient distribution and number of patients treated (L.-J. E. Ku, Chiou, \& Liu, 2015). The three FKTP studied by Kurnia have higher capitation tariff patterns in the age group $0-4$ years and $\geq 50$ years and tend to fall in the productive age group because utilization rates can 
vary between different age groups (Kurnia \& Nurwahyuni, 2017). This occurs because capitation expenditure is also determined from the risk collection of registered participants. From the results of these studies it can be concluded that the total receipt of capitation funds will be fairer if it is made per risk mix for the primary health care facilities (Fasilitas Kesehatan Tingkat Pertama/FKTP), because the capitation funds received will be adjusted to the main factors of utilization of health services, one of which is age. It is very important to map the participant's risk mix so that capitation and reference numbers are adjusted to the participant's risk.

\subsubsection{Suspicion of Fraud in Health Facilities}

According to the explanation of this research informant, cases of alleged fraud that often occur in health facilities are cases of upcoding, readmission and unbundling. The alleged fraud case also occurred in other countries (Bauder et al., 2017; Kim et al., 2013). Within one year, the proportion of stroke patients who experienced readmission was $5 \% .{ }^{27}$ However, the alleged fraud case based on the results of this study was included in the low category. The information (from the informant) is as follows.

There is such a thing as an audit for fraud ... if we look at the data as a whole, the case is not too big (BPJS-Healh).

It's small, because the Badan Pengawasan Keuangan dan Pembangunan (BPKP) audit has a potential of IDR 27 billion. That's a measly claim at nearly 100 T. (Ministry of Health).

Fraud is more related to upcoding and readmission. There is also a lot of unbundling, so the claims are separated, right? (BPJS-Healh).

One of the efforts to prevent the occurrence of fraud cases is by increasing the capacity of verifiers to find suspected fraud cases (Bauder et al., 2017). Moreover, based on the recommendation of expert informants, implementation of medical audits in health facilities need to be improved so that medical personnel accused of fraud can be dealt with immediately.

Internal medical audits are carried out in a hospital, right in that hospital there is a medical committee ... now it is carried out (Academic Expert 3).

This will also improve the quality of hospitals to remain entrusted to contract with BPJS-Health.

3.2.3 The Back-Referral Mechanism Does not eventually work from secondary healthcare (Fasilitas Kesehatan Tingkat Lanjut/FKTL) to Primary Healthcare (FKTP), Tiered Referral Between Hospital Classes Causes Overutilization

Some research results in several regions in Indonesia show that non-specialist referral cases have increased (Alawi et al., 2017; Faulina et al., 2017; Nazriati et al., 2015). This result has similarities with the opinions of the informants interviewed in this study. Facts that occur in other countries show that the utilization of health services for patients participating in NHI has increased as has the case for referral after capitation payments have been applied especially in cases of chronic disease (Andoh-Adjei et al., 2018; Dong et al., 2019). According to Daramola, a number of factors have been shown to influence referral, namely the severity of the disease, community impressions with regard to referral facilities, costs, time, geographical accessibility of resources available in primary health care and trained personnel among various levels of health services (Daramola, Adesina, \& Akande, 2019). Some of the efforts that have been made by the Indonesian government, in accordance with the results of this study, is namely by applying Commitment-Fulfillment Based Capitation (Kapitasi Berbasis Komitmen/KBK), tiered referral and a back-referral program. The following is the implementation of back-referral mechanism in JKN.

The case in back referral is hospital not returned the patient to the FKTP. It is also communication problems between FKTP and FKTL. There is still miscommunication between doctor in FKTP and doctor's specialist in FKTL (Puskesmas Pasir Panjang).

It is often debate between doctor and patient in Poli. The patient insisted on asking for referrals to the Puskesmas doctor. The patient also does not bring a back-referral sheet from hospital doctor when they visit Puskesmas doctor (Puskesmas Wonoayu).

Some countries allow participants to directly access advanced health facilities' fee-for-service payments while other countries continue to implement gate keepers and tiered referrals. China launched health service reforms by reintroducing the tiered referral system as a solution to reduce over-utilization in regional hospitals and control the cost of health services (Feng et al., 2017). Unfortunately, the results of this study suggest that tiered referral in secondary health facilities makes lead to overutilization. This makes the claim for one patient who has a tiered referral more expensive. Advice from expert informants on referrals based on health service competencies is a new recommendation that can be applied to prevent an increase in the burden of such claims. 


\subsubsection{Cases of Catastrophic Disease in Hospitals}

Besides being a reference, the utilization of expensive diseases is one of the causes of the deficit based on the results of this study. BPJS-Health mentions the term with catastrophic disease. Table 3 shows the list of the largest catastrophic diseases that are the obligation of BPJS-Health claims to health facilities.

Tabel 3. Catastrophic Diseases 2018-Agust 2019

\begin{tabular}{|c|c|c|c|c|}
\hline \multirow{2}{*}{ Catastrophic } & \multicolumn{2}{|l|}{2018} & \multicolumn{2}{|l|}{ Until August 2019} \\
\hline & Cost (IDR) & $\%$ & Cost (IDR) & $\%$ \\
\hline Heart Disease & $10,545,485,639,809$ & $51.62 \%$ & $7,732,780,546,565$ & $50.21 \%$ \\
\hline Kidney Failure & $2,395,347,020,362$ & $11.72 \%$ & $1,802,573,335,938$ & $11.70 \%$ \\
\hline Cancer & $3,406,308,675,470$ & $16.67 \%$ & $2,715,553,351,080$ & $17.63 \%$ \\
\hline Stroke & $2,565,601,469,065$ & $12.56 \%$ & $1,938,775,615,316$ & $12.59 \%$ \\
\hline Thalassaemia & $490,997,712,556$ & $2.40 \%$ & $387,902,570,646$ & $2.52 \%$ \\
\hline Cirrhosis Hepatis & $334,220,059,770$ & $1.64 \%$ & $245,234,149,691$ & $1.59 \%$ \\
\hline Leukemia & $333,326,835,880$ & $1.63 \%$ & $283,525,496,250$ & $1.84 \%$ \\
\hline Haemophilia & $358,121,722,285$ & $1.75 \%$ & $294,996,010,623$ & $1.92 \%$ \\
\hline Total Catasthropic & \multicolumn{2}{|c|}{$20,429,409,135,197$} & \multicolumn{2}{|c|}{$15,401,341,076,109$} \\
\hline Total Cost Services & \multicolumn{2}{|c|}{$94,297,340,885,513$} & \multicolumn{2}{|c|}{$71,287,635,875,988$} \\
\hline \% Catasthropic Costs to Health Services Costs & \multicolumn{2}{|l|}{$21.66 \%$} & \multicolumn{2}{|l|}{$21.60 \%$} \\
\hline
\end{tabular}

Source: BPJS-Health 2019.

The definition of catastrophic according to WHO is the payment of health services reaching more than $40 \%$ of total household income (Nugraheni WP, 2017; Xu et al., 2005). The essence is not to eliminate the benefits of expensive diseases, but as to strengthening of primary services and developing health screening tool are needed as an early prevention effort from delays in the management of chronic diseases (Hartono, 2017). In Thailand a comprehensive benefit package is carried out by strengthening non-communicable diseases prevention services in primary care prior to the complications of claims for expensive diseases (Patcharanarumol et al., 2016).

\section{Conclusion}

The causes of the JKN deficit in the aspect of income are namely: 1) the determination of the amount of contributions not yet in accordance with actuarial calculations, 2) there is no periodic increase in JKN participant's contribution amount, 3) the upper limit of income used in calculating PPU participants 'contributions is still relatively low, 4) the collectivity of PBPU and BP (not a worker/Bukan Pekerja/BP) participants' contributions is low, and income JKN funding has not been optimally obtained from other sources (for example from cigarette taxes), sugary tax, alcohol tax, or other food taxes imposing negative externalities to health.

The causes of JKN deficit in expenditure aspects include: 1) the implementation of individual preventive and promotive benefit packages have not run optimally, 2) the determination of capitation value has not been set in accordance with health risks, 3) the back-referral mechanism does not work from secondary level provider (FKRTL) to primary level provider (FKTP), 4) tiered referral to certain hospital classes causes overutilization, 5) high claims for cases of catastrophic disease in hospitals.

\section{Recommendation}

This study provides solution as to handling the JKN deficit both in short- and long-term in accordance considering the funding of JKN as well as its expenditure. The proposed solution can be deemed as alternative policies to mitigate such impact.

\section{Acknowledgments}

The Authors thank to the National Institute of Health Research and Development, Ministry of Health Republic of Indonesia, Jakarta, Indonesia which provides funds for the continuity of this study. the authors also thank to all of informants who have contributed to this study. 


\section{Funding Statement}

This study project was funded by the National Institute of Health Research and Development, Ministry of Health Republic of Indonesia, Jakarta, Indonesia.

\section{Competing Interest Statement}

The authors declare that there is no conflict interest.

\section{References}

Alawi, M., Junadi, P., \& Latifah, S. N. (2017). Analisis Faktor-Faktor yang Berhubungan dengan Tingginya Rujukan Kasus Non Spesialistik Pasien Jaminan Kesehatan Nasional pada Puskesmas di Kabupaten Sukabumi Tahun 2015. Jurnal Ekonomi Kesehatan Indonesia, 2(1). https://doi.org/10.7454/eki.v2i1.1954

Andoh-Adjei, F.-X., Boudewijns, B., Nsiah-Boateng, E., Asante, F. A., van der Velden, K., \& Spaan, E. (2018). Effects of capitation payment on utilization and claims expenditure under National Health Insurance Scheme: a cross-sectional study of three regions in Ghana. Health Economics Review, 8(1). https://doi.org/10.1186/s13561-018-0203-9

Bauder et al. (2017). A survey on the state of healthcare upcoding fraud analysis and detection. Health Services and Outcomes Research Methodology, 17(1), 31-55. https://doi.org/10.1007/s10742-016-0154-8

Bonfert, A. T., Hennig, J., Heymann, M., Hussein, K., Langenbrunner, J., \& Özaltin, A. (2015). Closing the gap: Health Coverage for Non-Poor Informal Sector Workers.

BPJS Kesehatan. (2019). Update Pengelolaan Program JKN-KIS. Jakarta: Badan Penyelenggara Jaminan Sosial Kesehatan Indonesia.

Chae, Y. H. (2019). Minimum Wage Make Simple. Retrieved May 27, 2020, from https://koreajoongangdaily.joins.com/2019/01/20/economy/Debriefing-Minimum-wage-made-simple/30584 10.html

Daramola, O. E., Adesina, C. T., \& Akande, T. M. (2019). Referral services under the national health insurance scheme; A hospital-based descriptive cross-sectional study in Abuja, Nigeria. World Journal of Innovative Research, 6(2), 134-138.

Deloitte. (2013). International Social Security Report. Retrieved May 28, 2020, from http://www.internationalsocialsecurity.eu/DRead/ISS_Study_Rates_and_Caps.pdf

Deloitte. (2016). EU Social Security Survey. Retrieved May 28, 2020, from https://www2.deloitte.com/content/dam/Deloitte/cz/Documents/survey/EU-Social-Security-Survey.pdf

Dong, Y., Chen, J., Jing, X., Shi, X., Chen, Y., Deng, X., ... \& Ma, J. (2019). Impact of capitation on outpatient expenses among patients with diabetes mellitus in Tianjin, China: a natural experiment. BMJ Open, $9(6)$, http://dx.doi.org/10.1136/bmjopen-2018-024807

Faulina et al. (2017). Kajian Pelaksanaan Sistem Rujukan Berjenjang dalam Program Jaminan Kesehatan Nasional (JKN) di UPT. Pelayanan Kesehatan Universitas Jember. IKESMA, 12(2).

Feng, D., Zhang, D., Li, B., Zhang, Y., Serrano, R., Shi, D., ... \& Zhang, L. (2017). Does having a usual primary care provider reduce patient self-referrals in rural China's rural multi-tiered medical system? A retrospective study in Qianjiang District, China. BMC Health Services Research, 17(1), https://doi.org/10.1186/s12913-017-2673-6.

Hartono, R. K. (2017). Global Stakeholder Schemes for Preventing Non-Communicable Disease, Lessont Learnt for Indonesia. International Conference of Social Science, 1(1), 50.

Hasan, A. (2017). Inovasi Pendanaan Defisit Program JKN-KIS Melalui Pungutan (Tambahan) atas Rokok untuk Kesehatan (PRUK). Jakarta: BPJS Kesehatan.

He, A. J., \& Wu, S. (2017). Towards universal health coverage via social health insurance in China: systemic fragmentation, reform imperatives, and policy alternatives. Applied Health Economics and Health Policy, 15(6). https://doi.org/10.1007/s40258-016-0254-1

Hidayat, B. (2016). Terapi Sistemik Defisit JKN: Bahan Refleksi Bagi Semua Pihak. Jurnal Ekonomi Kesehatan Indonesi, 1, 65-71.

Jeong, H.-S. (2011). Korea's National Health Insurance — Lessons from The Past Three Decades. Health Affairs, 1(1). https://doi.org/10.1377/hlthaff.2008.0816 
Kim, R. B., Kim, B.-G., Kim, Y.-M., Seo, J. W., Lim, Y. S., Kim, H. S., .. \& Shin, J.-Y. (2013). Trends in the incidence of hospitalized acute myocardial infarction and stroke in Korea, 2006-2010. Journal of Korean Medical Science, 28(1). https://doi.org/10.3346/jkms.2013.28.1.16

Ku, L.-J. E., Chiou, M.-J., \& Liu, L.-F. (2015). Variations in the persistence of health expenditures and the implications for the design of capitation payments in Taiwan. Journal of Health Services Research \& Policy, 20(3). https://doi.org/10.1177/1355819615577711

Ku, Y. (2006). Healthy Democracies: Welfare Politics in Taiwan and South Korea. Joseph Wong. The China Journal. https://doi.org/10.2307/20066175

Kurnia, A. N., \& Nurwahyuni, A. (2017). Analisis Perhitungan Kapitasi pada Fasilitas Kesehatan Tingkat Pertama yang Bekerja Sama dengan BPJS Kesehatan KCU Kota Bogor Tahun 2015. Jurnal Ekonomi Kesehatan Indonesia, 2(1).

Kwon, S. (2009). Thirty years of national health insurance in South Korea: Lessons for achieving universal health care coverage. Health Policy and Planning, 24(1), 63-71. https://doi.org/10.1093/heapol/czn037

Lee, Y.-C., Huang, Y.-T., Tsai, Y.-W., Huang, S.-M., Kuo, K. N., McKee, M., \& Nolte, E. (2010). The impact of universal National Health Insurance on population health: the experience of Taiwan. BMC Health Services Research, 10(1), 225. https://doi.org/10.1186/1472-6963-10-225

Liang et al. (2013). The long march to universal coverage: lessons from China. The World Bank, (UNICO Studies Series No. 9), 49.

Mulyadita, U. (2019). Analisis Ability To Pay (ATP) Iuran Jaminan Kesehatan Nasional Masyarakat Indonesia (Data Susenas 2017). Universitas Indonesia.

Nazriati et al. (2015). Profil Rujukan Kasus Nonspesifik pada Fasilitas Kesehatan Tingkat Primer. Kesmas: National Public Health Journal, 9(4), 327-332. https://doi.org/10.21109/kesmas.v9i4.739

Noeraini, A. A. (2015). Ekonomi Informal di Indonesia, Suatu Tinjauan Pustaka. Proceeding Seminar Nasional \& Call for Papers (SCA 5), 5.

Nugraheni, W. P., H. R. K. (2017). Catastrophic Health Spending Determinants of Indonesian Household in the First Year Implementation of JKN Program. Bul Penelit Kesehat, 45(1), 27-36.

Oxford Policy Management. (2016). Financing for Universal Health Coverage in low - and middle - income countries: a brief overview. Oxford.

Patcharanarumol, W., Panichkriangkrai, W., Wangmo, S., Thammatacharee, J., Uechi, M., \& Wanwong, Y. (2016). Diabetes prevention and care in the universal health coverage context: the example of Thailand. WHO South-East Asia Journal of Public Health, 5(1), 27.

Tangcharoensathien, V., Patcharanarumol, W., Ir, P., Aljunid, S. M., Mukti, A. G., Akkhavong, K., ... Mills, A. (2011). Health-financing reforms in southeast Asia: Challenges in achieving universal coverage. The Lancet, 377(9768), 863-873. https://doi.org/10.1016/S0140-6736(10)61890-9

Xu, K., Xu, K., Evans, D., Evans, D., Carrin, G., Carrin, G., ... Aguilar-Rivera, A. M. (2005). Designing health financing systems to reduce catastrophic health expenditure. Bulletin of the World Health Organization, 85(09), 8. https://doi.org/10.1017/CBO9781107415324.004

\section{Copyrights}

Copyright for this article is retained by the author(s), with first publication rights granted to the journal.

This is an open-access article distributed under the terms and conditions of the Creative Commons Attribution license (http://creativecommons.org/licenses/by/4.0/). 